\title{
Proizvodnja bioetanola iz kukuruznih oklasaka
}

\author{
M. Ivančić Šantek, I. Zvonar, S. Beluhan i B. Šantek \\ Zavod za biokemijsko inženjerstvo, Prehrambeno-biotehnološki fakultet Sveučilište u Zagrebu, \\ Pierottijeva 6, 10000 Zagreb
}

\begin{abstract}
Sažetak
Bioetanol je proizveden procesom istodobne saharifikacije i fermentacije (eng. Simultaneous saccharification and fermentation, SSF) s kvascem Saccharomyces cerevisiae na enzimskom hidrolizatu predobrađenih kukuruznih oklasaka. Istraživan je učinak trajanja predhidrolize kukuruznih oklasaka na učinkovitost procesa proizvodnje bioetanola te je uspoređen s konvencionalnim procesom SSF. Dvije smjese komercijalno dostupnih enzima rabljene su za hidrolizu sirovine; prva je sadržavala Celluclast 1.5L (Sigma) i $\beta$-glukozidazu (Carl Roth), a druga smjesa Celluclast 1.5L (Sigma) i Viscozyme L (Sigma).

Dva dana predhidrolize imala su pozitivan učinak na prinos bioetanola, dok je dulje trajanje predhidrolize smanjilo prinos bioetanola. Najveća koncentracija etanola od 41,24 $\mathrm{g} \mathrm{dm}^{-3}$ postignuta je u procesu SSF uz dva dana predhidrolize koja je iznosila 63,15 \% teoretskog iskorištenja izračunatog na neobrađeni kukuruzni oklasak. Najveća ukupna produktivnost procesa od 0,36 $\mathrm{g} \mathrm{dm}^{-3} \mathrm{~h}^{-1}$ postignuta je konvencionalnim SSF-om uz enzimsku smjesu koja je sadržavala Celluclast 1.5L (Sigma) i Viscozyme L (Sigma). Koncentracija etanola iznosila je 36,6 $\mathrm{g} \mathrm{dm}^{-3}$, što je 56,02 \% teoretskog prinosa etanola na neobrađeni kukuruzni oklasak.
\end{abstract}

\section{Ključne riječi}

Kukuruzni oklasci, bioetanol, celulaze, istodobna saharifikacija i fermentacija, predhidroliza

\section{Uvod}

Lignocelulozna biomasa najzastupljeniji je obnovljivi izvor organskog ugljika na Zemlji. Posljednjih desetljeća proveden je velik broj istraživanja vezanih uz primjenu te sirovine u proizvodnji biogoriva i finih kemikalija. Smatra se pogodnom zamjenom za naftu kao sirovina za proizvodnju motornih goriva jer je sveprisutna, lako dostupna i vrlo jeftina. ${ }^{1}$ Primjena lignocelulozne biomase u proizvodnji biogoriva pridonijela bi smanjenju niza gorućih problema s kojima je današnje društvo suočeno. To se prije svega odnosi na iscrpljivanje zaliha fosilnih goriva, energetsku nesigurnost i ovisnost, visoku razinu $\mathrm{CO}_{2} \mathrm{u}$ atmosferi i emisiju toksičnih supstancija koje nastaju izgaranjem fosilnih goriva $\left(\mathrm{SO}_{2}, \mathrm{NO}_{\mathrm{x}}\right)$. Proizvodnja bioetanola danas se najvećim djelom zasniva na šećernim (npr. šećerna repa i melasa) i škrobnim sirovinama (npr. kukuruzu, pšenici, krumpiru) koje se rabe u ishrani ljudi i stoke. $U$ mnogim razvijenim državama potiče se proizvodnja biogoriva različitim poreznim olakšicama i primjenom zakona o obvezatnom miješanju bioetanola s benzinom. Međutim uvedene mjere dovele su proizvođače hrane u neravnopravan položaj u odnosu na proizvođače biogoriva i uzrokovale porast cijene sirovine i hrane. ${ }^{2}$

Proces proizvodnje bioetanola iz lignoceluloznih sirovina biotehnološkim postupkom složen je i još uvijek komercijalno neisplativ proces. Na troškove proizvodnje bioetanola znatno utječe vrsta lignocelulozne biomase, ali i sam tehnološki proces proizvodnje (predobrada, hidroliza

*Autor za dopisivanje: Izv. prof. dr. sc. Mirela Ivančić Šantek e-pošta: mivancicsantek@pbf.hr lignocelulozne sirovine, fermentacija, izolacija i pročišćavanje proizvoda). Uspoređivanjem nekoliko pogona za proizvodnju bioetanola, utvrđeno je da troškovi proizvodnje po litri goriva iznose od 0,5 (Raizen, Brazil) pa čak i do 1,09 US\$ (Abengoa Bioenergy, SAD), što je u usporedbi s cijenom etanola proizvedenog iz škrobnih sirovina dvostruko više. ${ }^{3}$

Lignocelulozna biomasa sastoji se od celuloze (33 - $40 \%$ ), hemiceluloze $(20-25 \%)$ i lignina $(15-20 \%) .{ }^{4}$ Celuloza je homopolimer sastavljen od molekula D-glukoze povezanih $\beta(1,4)$-glikozidnom vezom. Prosječni broj molekula glukoze u lancu celuloze iznosi oko $14000 .{ }^{5}$ Hidroksilne skupine u celulozi stvaraju velik broj vodikovih veza unutar istog lanca i između usporedno posloženih lanaca. Međusobno povezani lanci celuloze vodikovim vezama tvore tzv. osnovna vlakna. Osnovna celulozna vlakna povezana su u mikrovlakna čija duljina ovisi o vrsti biljke i tkiva. ${ }^{5,7,10}$ Celulozna mikrovlakna međusobno su povezana $\mathrm{s}$ hemicelulozom te su prekrivena ligninom. Hemiceluloza je amorfni heteropolisaharid građen od šećera pentoza (ksiloza i arabinoza) i heksoza (glukoza, galaktoza i manoza), te u manjoj mjeri i od šećernih kiselina (glukuronske, metil-glukuronske i galakturonske kiseline). Broj jedinica šećera u lancu hemiceluloze iznosi oko $200 .{ }^{5}$ Treći strukturni polimer u lignoceluloznoj sirovini je lignin, amorfni heteropolimer, koji se sastoji od fenilpropanskih jedinica (kumaril alkohol, koniferil alkohol i sinapil alkohol) povezanih brojnim i različitim vrstama kemijskih veza. ${ }^{6}$ Lignin tvori nepropusnu prepreku u staničnoj stijenci a uz mehaničku čvrstoću biljci pruža fizičku zaštitu od oksidacijske i mikrobne razgradnje. ${ }^{6,7}$ 
Proces proizvodnje bioetanola iz lignoceluloznih sirovina sastoji se od četiri osnovna koraka: predobrada sirovine, hidroliza strukturnih ugljikohidrata (saharifikacija), fermentacija, izdvajanje i pročišćavanja etanola. Hidroliza celuloze do fermentabilnih šećera provodi se najčešće celulolitičkim enzimima izoliranim iz plijesni Trichoderma reesei i Aspergillus niger. ${ }^{8}$ Stupanj enzimske hidrolize celuloze iz izvorne lignocelulozne sirovine vrlo je malen, zbog sloja lignina i hemiceluloze koji obavijaju celulozna vlakna i onemogućuju vezanje enzima na supstrat. Osim toga, nativna celuloza u biomasi većim dijelom je u kristaličnom obliku, koju celulaze znatno sporije hidroliziraju od amorfne celuloze. ${ }^{9}$ Zbog toga se lignocelulozna sirovina podvrgava procesu predobrade čija je osnovna svrha povećanje iskorištenja enzimske hidrolize sirovine. Procesom predobrade u lignoceluloznoj sirovini smanjuje se udjel lignina i hemiceluloze, smanjuje se kristaličnost i stupanj polimerizacije lanaca celuloze te se povećava strukturna poroznost sirovine. Razvijen je velik broj metoda predobrade lignoceluloznih sirovina, a dijele se na fizikalne (npr. usitnjavanje, zračenje, ekstruzija, piroliza), kemijske (npr. ozonoliza, hidroliza s kiselinama i lužinama, oksidativna delignifikacija, organosolv postupak), fizikalno-kemijske (npr. eksplozija vodenom parom, eksplozija vlakana s amonijakom, eksplozija s $\mathrm{CO}_{2}$ ) i biološke metode (primjenom npr. celulolitičkih enzima, gljiva bijelog i smeđeg truljenja). ${ }^{10}$

Jedna od najčešće primjenjivanih metoda predobrade lignoceluloznih sirovina je alkalna hidroliza. Najčešće se upotrebljavaju natrijeva lužina, kalcijev i kalijev hidroksid, tekući amonijak, amonijev hidroksid i natrijev hidroksid s vodikovim peroksidom. ${ }^{10-13}$ Alkalnom predobradom učinkovito se razgrađuje lignin uz djelomičnu razgradnju hemiceluloze. Udjel razgrađenog lignina ovisi o uvjetima predobrade tj. koncentraciji natrijeve lužine, temperaturi i trajanju predobrade. ${ }^{11} \mathrm{U}$ alkalnoj sredini dolazi do hidrolize aril eterskih veza u ligninu, koji čine 50 - 70 \% ukupnih veza pri čemu se oslobađa natrij fenolat. Nadalje, jako alkalna sredina uzrokuje solvataciju hidroksilnih skupina u ugljikohidratima, što ima posljedicu bubrenja celuloznih vlakana i povećanja unutarnje površine, smanjenja stupnja polimerizacije i kristaličnosti celuloze. Saponifikacijom acetilnih i uronskih esterskih veza u hemicelulozi omogućava se fizički kontakt enzima i supstrata čime se povećava učinkovitost enzimske hidrolize. Alkalna predobrada pokazala se vrlo učinkovitom u predobradi sirovina s manjim udjelom lignina kao što su ostatci tvrdog drveta i različiti poljoprivredni ostatci [divlje proso (eng. switchgrass), kukuruzni oklasak, pšenična i rižina slama, rižina ovojnica]. ${ }^{14,20-23}$

Inhibicija produktom i međuproduktom reakcije (glukoza i celobioza) karakteristična je za enzimsku hidrolizu celuloze, posebno u podlogama s visokom koncentracijom supstrata. Inhibicijski učinak produkata hidrolize može se smanjiti provedbom istodobne saharifikacije i fermentacije (eng. Simultaneous saccharification and fermentation, SSF). ${ }^{24} \mathrm{U}$ procesu SSF koncentracija fermentabilnih šećera održava se dovoljno niskom njihovom istodobnom konverzijom u etanol djelovanjem kvasca Saccharomyces cerevisiae. Osnovni nedostatak procesa SSF je temperatura pri kojoj se provodi fermentacija i enzimska hidroliza sirovine. Naime, proces SSF provodi se pri temperaturi optimalnoj za rast kvasca $\left(35^{\circ} \mathrm{C}\right)$ koja je znatno niža od optimalne temperature za enzimsku hidrolizu $\left(50{ }^{\circ} \mathrm{C}\right)$. Zbog znatno niže celulolitičke aktivnosti pri nižim temperaturama potrebno je povećati količinu enzima za hidrolizu, što povećava troškove proizvodnje. Učinkovitost procesa SSF može se povećati tako da se lignocelulozna sirovina podvrgne predhidrolizi pri $50{ }^{\circ} \mathrm{C}$ neposredno prije inokulacije podloge. ${ }^{15,16}$

U ovom radu istražena je mogućnost proizvodnje bioetanola iz kukuruznih oklasaka procesom SSF. Učinak predhidrolize sirovine i dodatka enzimskih preparata $\beta$-glukozidaze i Viscozyme L na učinkovitost procesa procijenjena je usporedbom tri ključna pokazatelja uspješnosti bioprocesa (produktivnost, prinos i iskorištenje).

\section{Eksperimentalni dio}

\section{Supstrati, enzimi i kemikalije}

Kukuruzni oklasci su obrani u listopadu 2015. u okolici Ludbrega (geografska širina/dužina: 46 $16^{\prime} 00^{\prime \prime} \mathrm{S} / 16^{\circ}$ $36^{\prime} 36^{\prime \prime}$ I). Suhi kukuruzni oklasci usitnjeni su u drobilici za vrtni otpad (Hurricane HMH 200, Njemačka), a zatim u reznom mlinu (Retsch SM 2000, Germany). Usitnjena sirovina prosijana je kroz sito veličine otvora $1 \mathrm{~mm}$ te je frakcija sirovine veličine granulacije $<1 \mathrm{~mm}$ pohranjena u plastične posude. Sirovina je čuvana na sobnoj temperaturi u suhoj i tamnoj prostoriji. Količina vlage u sirovini iznosila je približno $5 \%$. U istraživanju su upotrijebljene sljedeće kemikalije: sladni agar (Difco, SAD), pepton (Carl Roth, Austrija), glukoza (Carl Roth, Austrija), etanol (Sigma, SAD), glicerol (Sigma, SAD), ksiloza (Sigma) i celobioza (Sigma) te različite mineralne soli za pripremu hranjive podloge (Kemika, Hrvatska).

Za hidrolizu kukuruznog oklaska upotrijebljeni su sljedeći enzimski preparati: celulaze iz plijesni Trichoderma reesei (Celluclast 1.5L, Sigma, SAD), Viscozyme L (Sigma, SAD) i $\beta$-glukozidaza izolirana iz badema (Carl Roth, Austrija).

\section{Mikroorganizam}

U istraživanju upotrijebljen je soj kvasca Saccharomyces cerevisiae (V07) iz zbirke mikroorganizama Laboratorija za biokemijsko inženjerstvo, industrijsku mikrobiologiju i tehnologiju piva i slada, Prehrambeno-biotehnološkog fakulteta u Zagrebu. Kultura je održavana na sladnom agaru (6\%). Predkultura je uzgojena u tekućem mediju (YPD) koji je sadržavao $20 \mathrm{~g} \mathrm{dm}^{-3}$ glukoze, $20 \mathrm{~g} \mathrm{dm}^{-3}$ peptona i $10 \mathrm{~g} \mathrm{dm}^{-3}$ kvaščeva ekstrakta. Inokulum je uzgojen na rotacijskoj tresilici pri $180 \mathrm{o} \mathrm{min}^{-1} \mathrm{i}$ temperaturi od $30{ }^{\circ} \mathrm{C}$ tijekom dva dana.

\section{Alkalna predobrada kukuruznih oklasaka}

Prethodno usitnjeni kukuruzni oklasci pomiješani su s 15 \%-tnom natrijevom lužinom uz omjer otopine lužine i sirovine $8: 1$ (masa volumen $^{-1}$ ). Smjesa je kuhana 30 min pri temperaturi $121^{\circ} \mathrm{C}$. Vrući hidrolizat filtriran je preko Büchnerova lijevka, a zatim je filtarski kolač ispran s de- 
mineraliziranom vodom do neutralne $\mathrm{pH}$ vrijednosti i osušen pri $50{ }^{\circ} \mathrm{C}$. Zračno suhi uzorak sadržavao je $5 \%$ vlage. Iskorištenje glukana i ksilana $\left(\eta_{\mathrm{PB}}\right)$ u procesu predobrade izračunata je iz omjera masa ugljikohidrata u obrađenoj i neobrađenoj sirovini.

\section{Određivanje enzimske aktivnosti}

Ukupna celulolitička aktivnost (eng. Filter Paper Assay, FPA) određena je prema propisu Međunarodne unije za čistu i primijenjenu kemiju (eng. International Union for Pure and Applied Chemistry, IUPAC). ${ }^{17} \mathrm{U}$ testu je određena količina enzima potrebna da se oslobodi $2 \mathrm{mg}$ glukoze enzimskom hidrolizom filtar-papira $(50 \mathrm{mg})$ tijekom $60 \mathrm{~min}$ pri $50{ }^{\circ} \mathrm{C}$. Ukupna celulolitička aktivnost enzimskog preparata izražena je kao FPU (eng. Filter Paper Units) po mililitru nerazrijeđenog enzimskog preparata.

$\beta$-glukozidazna aktivnost enzimskog preparata određena je s $15 \mathrm{mM}$ celobiozom u $50 \mathrm{mM}$ citratnom puferu $(\mathrm{pH}=4,8)$ pri temperaturi od $50{ }^{\circ} \mathrm{C}$ tijekom 30 min. ${ }^{18}$ Koncentracija glukoze određena je pomoću visokoučinkovite tekućinske kromatografije (HPLC) te je izračunata aktivnost enzima. Jedna jedinica $\beta$-glukozidazne aktivnosti (IU) definirana je kao količina enzima koja katalizira oslobađanje jednog $\mu$ mol glukoze po minuti u navedenim uvjetima enzimske reakcije.

\section{Enzimska hidroliza kukuruznih oklasaka i proizvodnja bioetanola}

Proizvodnja etanola iz predobrađenih kukuruznih oklasaka provedena je postupkom SSF. Istražen je učinak predhidrolize na učinkovitost procesa proizvodnje bioetanola. Pri tome su upotrijebljene dvije enzimske smjese; prva smjesa sadržavala je Celluclast 1.5 L (20 FPU g-1 glukana) i $\beta$-glukozidazu (30 IU g ${ }^{-1}$ glukana), a druga Cellulast $1.5 \mathrm{~L}$ (20 FPU g g glukana) i Viscozyme L $\left(0,2 \mathrm{ml} \mathrm{g}^{-1}\right.$ suhe tvari predobrađeng kukuruznog oklaska). Uzimajući u obzir $\beta$-glukozidaznu aktivnost Celluclast $1.5 \mathrm{~L}$, ukupna $\beta$-glukozidazna aktivnost prve enzimske smjese iznosila je 40 IU $g^{-1}$ glukana. Druga enzimska smjesa imala je ukupnu $\beta$-glukozidaznu aktivnost od $15 \mathrm{IU} \mathrm{g}^{-1}$ glukana. Količina predobrađenog kukuruznog oklaska u podlozi iznosila je $10 \%$ (masa masa-1), a ukupni volumen suspenzije iznosio je $100 \mathrm{ml}$. Enzimska hidroliza provedena je u $50 \mathrm{mM}$ citratnom puferu $(\mathrm{pH}=5,0)$ pri temperaturi od $50{ }^{\circ} \mathrm{C}$ uz miješanje na rotacijskoj tresilici (180 o $\mathrm{min}^{-1}$ ). Enzimski preparati sterilizirani su filtracijom kroz sterilni najlonski membranski filtar (pore otvora 0,2 $\mu \mathrm{m}$, Sartorius). Enzimska predhidroliza provedena je pri $50{ }^{\circ} \mathrm{C}$ tijekom 48, 96 i 144 sata. U radu su upotrijebljene sljedeće oznake za šest različitih istraženih uvjeta fermentacije: A $\beta$ (dodatak $\beta$-glukozidaze bez predhidrolize), A_V (dodatak Viscozyme $L$ bez predhidrolize), B_ $\beta$ (dodatak $\beta$-glukozidaze i $48 \mathrm{~h}$ predhidrolize), B V (dodatak Viscozyme L i $48 \mathrm{~h}$ predhidrolize), C $\beta$ (dodatak $\beta$-glukozidaze i $96 \mathrm{~h}$ predhidrolize), C_V (dodatak Viscozyme L i 96 h predhidrolize), D_ $\beta$ (dōatak $\beta$-glukozidaze i $144 \mathrm{~h}$ predhidrolize) i D_V (dodatak Viscozyme L i 144 h predhidrolize). Tijekom predhidrolize volumen podloge se smanjivao uslijed ispa- ravanja vode. Volumen smjese svakodnevno je korigiran na početnu vrijednost dodatkom vode. Po završetku enzimske hidrolize dodana je 100 x koncentrirana otopina kompleksnog izvora dušika i mineralnih soli potrebnih za rast kvasca. Nakon dodatka koncentriranih otopina u lignocelulozni hidrolizat koncentracije kompleksnog izvora dušika i mineralnih soli u podlozi za uzgoj iznosile su: kvaščev ekstrakt $2 \mathrm{~g} \mathrm{dm}^{-3},\left(\mathrm{NH}_{4}\right)_{2} \mathrm{SO}_{4} 5 \mathrm{~g} \mathrm{dm}^{-3}, \mathrm{KH}_{2} \mathrm{PO}_{4} 1 \mathrm{~g} \mathrm{dm}^{-3}$, $\mathrm{MgSO}_{4} \times 7 \mathrm{H}_{2} \mathrm{O} \mathrm{0,5} \mathrm{g} \mathrm{dm}^{-3}, \mathrm{FeSO}_{4} \times 7 \mathrm{H}_{2} \mathrm{O} \mathrm{0,01} \mathrm{g} \mathrm{dm}^{-3}$, $\mathrm{CaCl}_{2}$ 0,1 $\mathrm{g} \mathrm{dm}^{-3}, \mathrm{NaCl} 0,1 \mathrm{~g} \mathrm{dm}^{-3}$. Usporedno je proveden uzgoj konvencionalnim procesom SSF bez prethodne hidrolize sirovine. Podloga je inokulirana vlažnom kvaščevom biomasom izdvojenom centrifugiranjem $10 \mathrm{ml}$ suspenzije inokuluma uzgojenog u podlozi YPD. Nakon inokulacije tikvice su začepljene vreljnjačom te su inkubirane pri $30{ }^{\circ} \mathrm{C}$ tijekom deset dana na magnetskoj miješalici (130 rpm). Uzorci podloge $(0,5 \mathrm{ml})$ izuzimani su 0., 1. , 2., 3., 4., 6. i 10. dana uzgoja. U supernatantima prevrele podloge određena je koncentracija šećera i proizvoda metabolizma (etanol i glicerol).

\section{Analiza sastava lignocelulozne sirovine}

U izvornom i predobrađenom kukuruznom oklasku određen je udjel strukturnih ugljikohidrata (glukan, ksilan, arabinan) i ukupni lignin (topljiv i netopljiv u vodi) prema propisu američkog Nacionalnog laboratorija za obnovljivu energiju (eng. National Renewable Energy Laboratory). ${ }^{19}$ Neposredno prije analize uzorci su usitnjeni u tarioniku u fini prah.

Sastav strukturnih ugljikohidrata određen je kiselinskom hidrolizom sirovine. U tikvicu s okruglim dnom dodano je 0,4 g lignoceluloznog supstrata i $4 \mathrm{ml} 72 \%$-tne $\mathrm{H}_{2} \mathrm{SO}_{4}$ te je smjesa homogenizirana. Nakon jednog sata hidrolize pri sobnoj temperaturi sirovini je dodano $112 \mathrm{ml}$ demineralizirane vode. Smjesa je zagrijana do vrenja i kuhana 4 sata uz povratno hladilo. Nakon kiselinske hidrolize smjesa je profiltrirana kroz Büchnerov lijevak. U filtratu kiselinskog hidrolizata određena je koncentracija monosaharida HPLC-om. Zaostala sumporna kiselina u filtarskom kolaču ispirana je s demineraliziranom vodom do neutralnog pH. Filtarski kolač je osušen pri $105^{\circ} \mathrm{C}$ do konstantne mase te je njegova masa određena vaganjem. Udjel lignina netopljivog u kiselini u lignoceluloznoj sirovini jednak je omjeru mase suhog filtarskog kolača i mase lignocelulozne sirovine uzete $\mathrm{u}$ analizu $(0,4 \mathrm{~g})$.

U filtratu kiselinskog hidrolizata određen je udjel lignina topljivog u kiselini spektrofotometrijski pri valnoj duljini od $205 \mathrm{~nm}$. Udjel lignina topljivog u kiselini, w(ASL) izračunat je prema jednadžbi:

$$
w(\mathrm{ASL})=\frac{A_{205} \cdot D \cdot V}{\alpha \cdot b \cdot m}
$$

gdje je $A_{205}$ apsorbancija uzorka pri $205 \mathrm{~nm}, D$ faktor razrjeđenja uzorka, $V$ volumen uzorka $(0,112 \mathrm{I})$, $\alpha$ apsorpcijski koeficijent $\left(110 \mathrm{dm}^{3} \mathrm{~g}^{-1} \mathrm{~cm}^{-1}\right), b$ širina kivete $(1 \mathrm{~cm})$ i $\mathrm{m}$ masa uzorka uzetog u analizu $(0,4 \mathrm{~g})$.

Ukupni udjel lignina u suhoj tvari biomase suma je udjela lignina topljivog i netopljivog u kiselini. 


\section{Određivanje koncentracije šećera i produkata metabolizma pomoću tekućinske kromatografije visoke učinkovitosti (HPLC)}

Koncentracija glukoze, ksiloze i celobioze, te produkata metabolizma (etanol i glicerol) određena je uz pomoć uređaja Shimadzu CLASS-VP LC-10AVP (Japan) s detektorom indeksa loma (RID-10A). Analizirane komponente razdvajane su na analitičkoj koloni Supelcogel $\mathrm{C610H}$ (Supelco) uz predkolonu (Supelcogel H Guard Column, Sigma). Kao pokretna faza upotrijebljena je otopina $\mathrm{H}_{3} \mathrm{PO}_{4}(\varphi=0,1 \%)$. Temperatura pećnice bila je $55^{\circ} \mathrm{C}$ a brzina protoka pokretne faze $0,5 \mathrm{ml} \mathrm{min}{ }^{-1}$. Koncentracije šećera izračunate su iz jednadžbe baždarnog pravca za pojedini analit.

\section{FTIR analiza}

Snimanja spektara IR provedena su na uređaju ABB Bomem MB 102 FTIR spektrofotometru, u području valnih brojeva od 4000 do $450 \mathrm{~cm}^{-1}$. Lignocelulozna sirovina usitnjena je u prah u tarioniku te su pripremljene pastile s kalijevim bromidom.

\section{Izračunavanje udjela ugljikohidrata u lignoceluloznoj sirovini}

Udjel glukana i ksilana u lignoceluloznoj sirovini izračunava se iz koncentracije odgovarajućih monosaharida $\left(\gamma_{\text {msah }}\right)$ uz pomoć korektivnog faktora $\left(K_{\mathrm{f}}\right)$ prema sljedećoj jednadžbi:

$$
w(\mathrm{CHO})=\frac{\gamma_{\mathrm{msah}} \cdot V_{\text {hidr }} \cdot K_{\mathrm{f}}}{m_{\mathrm{uz}}} \cdot 100,
$$

gdje je $V_{\text {hidr }}$ volumen hidrolizata (I) i $m_{\mathrm{uz}}$ masa analiziranog uzorka $(0,4 \mathrm{~g})$.

Korektivni faktor predstavlja omjer molekulske mase monomerne građevne jedinice ugljikohidrata i monosaharida. Korektivni faktor za pentoze (ksiloza i arabinoza) je 0,88 (tj. 132/150), dok je za heksoze (glukoza, galaktoza i manoza) 0,9 (tj. 162/180).

\section{Pokazatelji uspješnosti bioprocesa}

Ukupna učinkovitost proizvodnje etanola iz kukuruznih oklasaka određena je prema tri ključna parametra: stupanj konverzije supstrata u proizvod izračunat na količinu glukana u predobrađenom kukuruznom oklasku $\left(Y_{\mathrm{P} / \mathrm{S}}\right)$ i na izvornu sirovinu $\left(\mathrm{Y}_{\mathrm{P} / \mathrm{SNKO}}\right)$, produktivnost $(\mathrm{Pr})$ i ukupna produktivnost procesa $\left(\operatorname{Pr}_{\mathrm{T}}\right)$ te iskorišenje $(\eta)$ i ukupno iskorištenje procesa $\left(\eta_{\mathrm{T}}\right)$.

Stupanj konverzije supstrata $\mathrm{u}$ etanol $\left(\mathrm{Y}_{\mathrm{P} / \mathrm{S}}\right)$ predstavlja omjer mase nastalog etanola $\left(m_{\mathrm{p}}\right)$ i mase glukana u predobrađenom kukuruznom oklasku $\left(m_{\text {glukan }}\right)$ :

$$
Y_{\mathrm{P} / \mathrm{S}}=\frac{m_{\mathrm{P}}}{m_{\text {glukan }}} .
$$

Ukupni stupanj konverzije neobrađenog kukuruznog oklaska u etanol $\left(Y_{\mathrm{P} / \mathrm{NKO}}\right)$ izračunat je prema sljedećoj jednadžbi:

$$
Y_{\mathrm{P} / \mathrm{NKO}}=\frac{m_{\mathrm{P}}}{m_{\text {glukan, OKO }} / \eta_{\mathrm{PB}}},
$$

gdje je $m_{\text {glukan, Око }}$ masa glukana u predobrađenom kukuruznom oklasku, a $\eta_{\mathrm{PB}}$ iskorištenje glukana u procesu predobrade.

Produktivnost bioprocesa proizvodnje etanola izračunata je prema sljedećoj jednadžbi:

$$
\operatorname{Pr}=\frac{m_{\mathrm{P}}}{t \cdot V}
$$

gdje je $V$ volumen podloge, a $t$ trajanje fermentacije.

Pri izračunu ukupne produktivnosti $\left(\operatorname{Pr}_{\mathrm{T}}\right)$ uzeto je u obzir i trajanje predhidrolize sirovine.

Učinkovitost bioprocesa predstavlja omjer eksperimentalno određenog i teoretskog stupnja konverzije glukana u etanol:

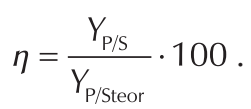

Teoretski stupanj konverzije glukana u etanol iznosi $0,567 \mathrm{gg}^{-1}$.

Ukupna učinkovitosti procesa definirana je jednadžbom:

$$
\eta_{\mathrm{T}}=\frac{Y_{\mathrm{P} / \mathrm{NKO}}}{Y_{\mathrm{P} / \text { Steoret. }}} .
$$

\section{Iskorištenje enzimske hidrolize glukana tijekom stupnja predhidrolize}

Iskorištenje enzimske reakcije hidrolize glukana do glukoze $\left(\eta_{\mathrm{EHG}}\right)$ i ksilana do ksiloze $\left(\eta_{\mathrm{EHK}}\right)$ tijekom stupnja predhidrolize izračunato je prema sljedećoj jednadžbi:

$$
\eta_{\mathrm{EH}}=\frac{m_{\text {msah }}}{\frac{m_{\mathrm{CHO}}}{K_{\mathrm{f}}}} \cdot 100,
$$

gdje je $m_{\text {msah }}$ masa monosaharida (glukoza, ksiloza) u enzimskom hidrolizatu kukuruznog oklaska, a $m_{\mathrm{CHO}}$ masa strukturnog ugljikohidrata (glukan, ksilan) u predobrađenom kukuruznom oklasku.

\section{Rezultati i rasprava}

U ovom radu istražen je učinak predhidrolize na učinkovitost procesa proizvodnje bioetanola iz lignocelulozne sirovine postupkom SSF. Kao supstrat za proizvodnju bioetanola odabrani su kukuruzni oklasci koji uz kukuruzovinu (stabljika s lišćem i komušinom) ostaju neiskorišteni nakon berbe kukuruza. Učinkovitost procesa proizvodnje etanola s kvascem S. cerevisiae ovisna je o dostupnom izvoru ugljika tj. glukozi koja nastaje enzimskom hidroli- 
zom glukana iz predobrađenog kukuruznog oklaska. Najzastupljeniji ugljikohidrati u kukuruznom oklasku bili su glukan (38,5 \%) i ksilan (36,1\%), dok je udjel galaktana, manana i arabinana bio vrlo malen $(<2 \%$; tablica 1$)$. Treća najzastupljenija komponenta u kukuruznom oklasku bio je lignin (19,8\%). Procesom predobrade s natrijevim hidroksidom, znatno je smanjen udjel lignina $(1,1 \%)$ i ksilana $(6,9 \%)$ u lignoceluloznoj sirovini. Taj postupak predobrade s natrijevom lužinom pokazao se učinkovitim u delignifikaciji lignoceluloznih sirovina s nižim udjelom lignina kao što su kukuruzni oklasci, kukuruzna stabljika, divlje proso (lat. Panicum virgatum, eng. switchgrass) i miscanthus (Miscanthus giganteus)..$^{14,20-23}$

Infracrvena spektroskopija (IR) primijenjena je u analizi sastava neobrađenog i predobrađenog kukuruznog oklaska (slika 1). Analizom FTIR spektara uočene su vrpce karakteristične za lignin, hemicelulozu i celulozu. ${ }^{25,26}$ Širok i jak signal u području od 3600 do $3000 \mathrm{~cm}^{-1}$ zapažen je u spektrima oba uzorka i potječe od rasteznih vibracija $\mathrm{O}-\mathrm{H}$ skupina prisutnih u sve tri najzastupljenije komponente lignocelulozne sirovine. ${ }^{26}$ Predobrada s natrijevom lužinom uklanja većinu lignina, što i potvrđuje smanjenje intenziteta vrpci karakterističnih za lignin u spektru predobrađenog uzorka: $1720 \mathrm{~cm}^{-1}$ i $1735 \mathrm{~cm}^{-1}$ (istezanje $\mathrm{C}=\mathrm{O}$ u ketonima, karboksi skupini estera i karbonilnim skupinama, ${ }^{25,26} 1605 \mathrm{~cm}^{-1}$ i $1515 \mathrm{~cm}^{-1}$ (istezanje aromatskog
Tablica 1 - Sastav neobrađenog i obrađenog kukuruznog oklaska Table 1 -Composition of the untreated and pretreated corn cobs

\begin{tabular}{l|c|c}
\hline Sastav & $\begin{array}{c}w \text { (neobrađeni } \\
\text { kukuruzni oklasak) } \\
\text { Composition }\end{array}$ & $\begin{array}{c}w(\text { obrađeni } \\
\text { kukuruzni oklasak) } \\
\text { corn cobs) } / \%\end{array}$ \\
$\begin{array}{c}w \text { (pretreated } \\
\text { corn cobs) } / \%\end{array}$ \\
\hline
\end{tabular}

ugljikohidrati/

carbohydrates

glukan/glucan

ksilan/xylan

ukupni lignin/total

lignin

38,5
36,1
19,8

85,7

6,9

1,1

prstena), ${ }^{25} 1235 \mathrm{~cm}^{-1}$ (istezanje $\mathrm{C}-\mathrm{C}, \mathrm{C}=\mathrm{O}$ i $\mathrm{C}-\mathrm{O}$ veza u gvajacilu), ${ }^{25,27} 1264 \mathrm{~cm}^{-1}$ (istezanje prstena gvajacila) ${ }^{25} \mathrm{i}$ $833 \mathrm{~cm}^{-1}$ (savijanje $\mathrm{C}-\mathrm{H}$ izvan ravnine na 2. i 6 . mjestu u prstenu siringilpropanske jedinice i sva mjesta u 4-hidroksi-fenilpropanske jedinice). ${ }^{28}$ Vrpca pri $1720 \mathrm{~cm}^{-1}$ ukazuje na prisutnost estera karboksilnih skupina koje se osim u ligninu nalaze i u hemicelulozi i kompleksima hemiceluloze i lignina. ${ }^{26}$ Smanjenje intenziteta tih vrpci u predobrađenoj sirovini ukazuje na smanjenje udjela lignina i hemiceluloze. Široka apsorpcijska vrpca srednjeg intenziteta pri $1253 \mathrm{~cm}^{-1}$ u spektru izvorne sirovine vjerojatno je

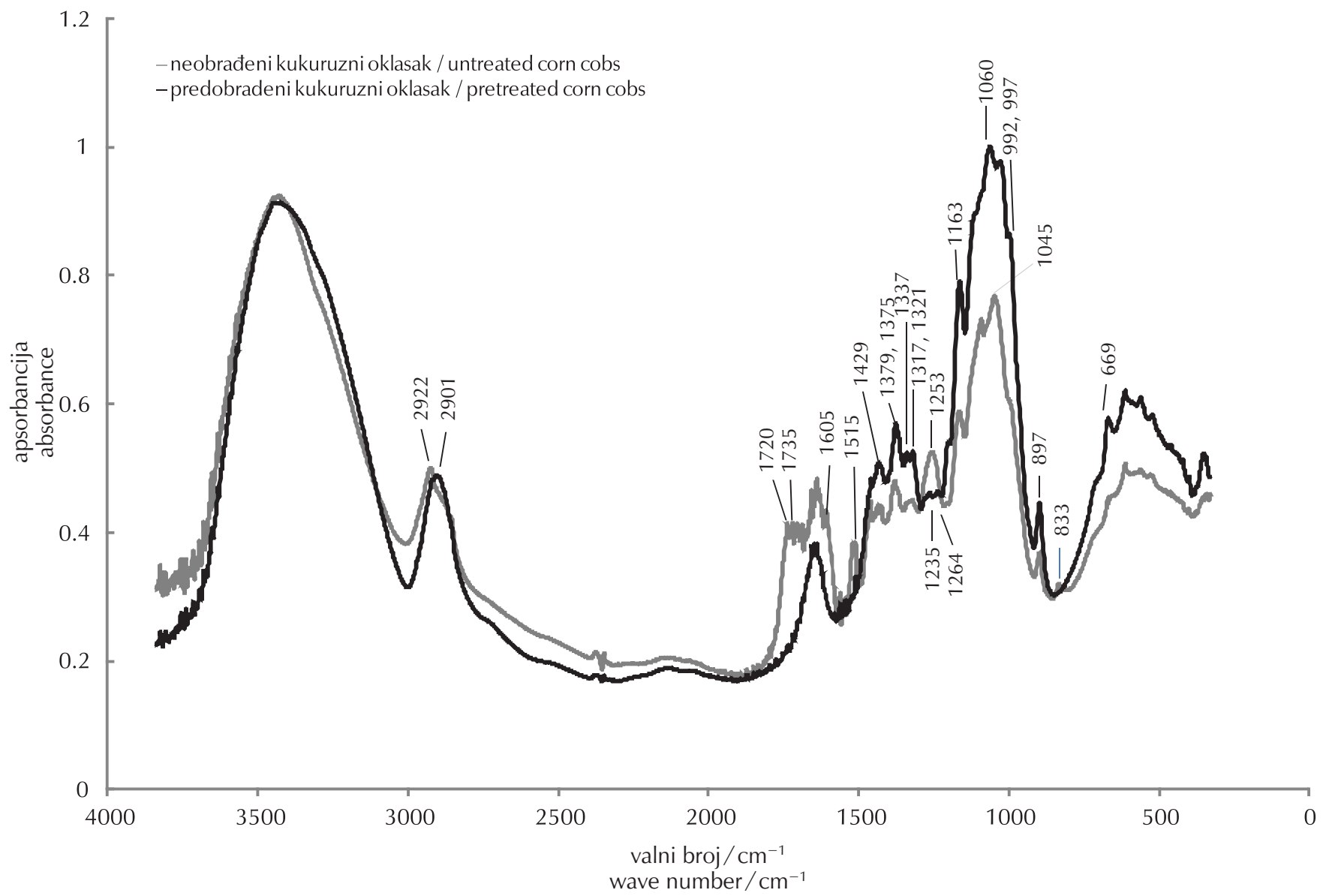

Slika 1 - Spektri FT-IR neobrađenih i obrađenih kukuruznih oklasaka

Fig. 1 - FT-IR spectra of untreated and pretreated corn cobs 
nastala spregom vibracija pri $1235 \mathrm{~cm}^{-1}$ i $1264 \mathrm{~cm}^{-1} \mathrm{koje}$ su pronađene u spektru predobrađenog uzorka. Apsorpcija pri $1235 \mathrm{~cm}^{-1}$ pripisuje se istezanju piranoznog prstena u celulozi, ${ }^{29}$ istezanje $\mathrm{O}-\mathrm{H}$ u hemicelulozi ${ }^{30}$ te $\mathrm{C}-\mathrm{H}$, $\mathrm{C}-\mathrm{O}$ i $\mathrm{C}=\mathrm{O}$ veza u gvajacilu. ${ }^{25,27}$ Slabiji intenzitet vrpce u spektru predobrađenog uzorka posljedica je smanjenja udjela lignina i hemiceluloze. Vrpca pri $1735 \mathrm{~cm}^{-1}$ osim za lignin karakteristična je za ksilan. Hidroksilne skupine ksilana djelomično su esterificirane s karboksilnim kiselinima: octenom (49\%), ferulinskom (4\%) i kumarinskom kiselinom (6\%). ${ }^{28}$ Smanjenje intenziteta te vrpce u predobrađenom uzorku posljedica je smanjenja udjela ksiloze.

Vrpce 897 i $1165 \mathrm{~cm}^{-1}$ [istezanje $\mathrm{C}-\mathrm{O}-\mathrm{C}$ veze u $\beta(1$, 4)-glikozidnoj vezi] karakteristične su za ksilan i celulozu. ${ }^{31}$ Povećanje intenziteta tih vrpci u predobrađenom uzorku može se protumačiti povećanjem sadržaja celuloze što je i potvrđeno kvantitativom analizom sirovine (tablica 1). Linearan i razgranati ksilan (kao što je glukuroksilan i arabinoksilan) imaju apsorpcijski maksimum pri $1044 \mathrm{~cm}^{-1}$, koji potječe od istezanja $\mathrm{C}-\mathrm{O}-\mathrm{C}$ veze i ukazuje na jaku kemijsku vezu između ksiloglukana i mikrofibrila celuloze. ${ }^{32,33}$ Vrpca s malim pomakom valne duljine $\left(1045 \mathrm{~cm}^{-1}\right)$ ukazuje na prisutnost ksilana u izvornoj sirovini. Pomicanje apsorpcijskog maksimuma vrpce s $2922 \mathrm{~cm}^{-1}$ (izvorna sirovina) na $2899 \mathrm{~cm}^{-1} \mathrm{i}$ smanjenje njezina intenziteta $\mathrm{u}$ spektru predobrađene sirovine ukazuje na povećanje kristaličnosti celuloze u uzorku. ${ }^{31}$

U nastavku istraživanja istražen je učinak predhidrolize sirovine i dodatak enzimskih preparata Viscozyme $L$ i $\beta$-glukozidaze na učinkovitost procesa proizvodnje bioetanola. Poznato je da tijekom hidrolize sirovine s celulazama iz plijesni T. reesei dolazi do nakupljanja celobioze koja je inhibitor celobiohidrolaza. ${ }^{33,34,35}$ Zbog male $\beta$-glukozidazne aktivnosti enzimskog preparata iz plijesni $T$. reesei (Cellulast $1.5 \mathrm{~L}$ ) dolazi do nakupljanja celobioze u hidrolizatu i manjeg iskorištenja enzimske hidrolize. Dodatkom $\beta$-glukozidaze u omjeru $\beta$-glukozidazne aktivnosti (IU) prema celulolitičkoj aktivnosti (FPU) enzimskog većim od 2: 1 IU $\mathrm{FPU}^{-1}$ povećava se iskorištenje enzimske hidrolize. ${ }^{35} \mathrm{Zbog}$ toga je u prvu enzimsku smjesu dodana $\beta$-glukozidaza, dok je u drugu dodan Viscozyme L. Preparat Viscozyme L sadrži izvanstanične enzime iz plijesni Aspergillus sp. i osim $\beta$-glukozidazne aktivnosti ima i celulolitičku, arabinaznu, hemicelulaznu i ksilanaznu aktivnost. ${ }^{36}$ Ahn i sur. (2012) utvrdili su da se dodatkom enzimskog preparata Viscozyme $L$ povećava brzina hidrolize lignocelulozne sirovine $u z$ znatno smanjenje viskoznosti smjese. ${ }^{37}$

Iskorištenja enzimske hidrolize glukana do glukoze i ksilana do ksiloze nakon 2., 4. i 6 . dana predhidrolize prikazana su u tablici 2. Dobiveni rezultati pokazali su da sastav enzimske smjese nije bitno utjecao na iskorištenje hidrolize. Unatoč dodatku $\beta$-glukozidaze nije postignuto veće iskorištenje u odnosu na dodatak Viscozyme L. Naime, dodatak $\beta$-glukozidaze najvjerojatnije je povećao brzinu enzimske hidrolize celobioze tijekom prvih sati hidrolize. Uslijed povećane $\beta$-glukozidazne aktivnosti dolazi do ubrzanog nakupljanja glukoze koja inhibira $\beta$-glukozidazu te porasta koncentracije celobioze. Porastom koncentracije celobioze dolazi do inhibicije celobiohidrolaza (egzoglukanaza) i postupnog usporavanja brzine hidrolize. . $3,34,35$ Veće iskorištenje hidrolize ksilana u odnosu na hidrolizu glukana posljedica su malog udjela ksilana u predobrađenoj sirovini. Iskorištenje enzimske hidrolize ksilana nakon 4. i 6. dana predhidrolize iznosio je više od $80 \%$ za obje enzimske smjese.

Smanjenje inhibicijskog učinka produkata enzimske reakcije na brzinu hidrolize supstrata može se postići provedbom procesa istodobne hidrolize i fermentacije (SSF). ${ }^{15,16}$ $\mathrm{U}$ tom procesu kombinira se enzimska hidroliza lignocelulozne sirovine uz istodobnu fermentaciju glukoze u etanol uz pomoć kvasca S. cerevisiae. Na slici 2 prikazane su koncentracije glukoze, celobioze, ksiloze, glicerola i etanola tijekom fermentacije hidrolizata kukuruznog oklaska. Tijekom prva tri dana uzgoja kvasac $S$. cerevisiae brzo previre glukozu u etanol. Najveće brzine previranja postignute su u reakcijskim smjesama $B \_\beta$ i B_V (dva dana predhidrolize; slika 2B). Brzina sinteze etanola u smjesi uz dodatak $\beta$-glukozidaze iznosila je $0,47 \mathrm{~g} \mathrm{dm}^{-3} \mathrm{~h}^{-1}$, a uz dodatak Viscozyme L 0,49 $\mathrm{g} \mathrm{dm}^{-3} \mathrm{~h}^{-1}$ (tablica 3). Nešto manje brzine sinteze etanola izmjerene su tijekom fermentacija $C \_\beta$

Tablica 2 - Iskorištenje enzimske hidrolize glukana $\left(\eta_{\mathrm{EHG}}\right)$ i ksilana $\left(\eta_{\mathrm{EHK}}\right)$ nakon predhidrolize predobrađenog kukuruznog oklaska s dvije enzimske smjese

Table 2 - Efficiency of enzymatic hydrolysis of glucan $\left(\eta_{\mathrm{EHG}}\right)$ and xylan $\left(\eta_{\mathrm{EHK}}\right)$ after prehydrolysis of pretreated corn cobs with two enzymatic mixtures

\begin{tabular}{|c|c|c|c|c|c|c|}
\hline $\begin{array}{l}\text { Enzimski preparat/ } \\
\text { Enzyme preparation }\end{array}$ & B_ $\beta^{c}$ & B_- $V^{d}$ & C__ $\beta^{e}$ & $C_{-} V^{f}$ & D_ $\beta^{g}$ & $D_{-} \mathrm{V}^{h}$ \\
\hline $\begin{array}{l}\text { predhidroliza } \\
\text { prehydrolysis / h }\end{array}$ & 48 & 48 & 96 & 96 & 144 & 144 \\
\hline glukoza/glucose $/ \mathrm{g} \mathrm{dm}^{-3}$ & 47,35 & 49,67 & 55,94 & 55,94 & 63,37 & 61,50 \\
\hline$\eta_{\mathrm{EHG}} / \%$ & 50,23 & 52,69 & 59,34 & 59,34 & 67,22 & 65,24 \\
\hline ksiloza/xylose/g dm ${ }^{-3}$ & 6,26 & 4,94 & 7,42 & 6,40 & 6,48 & 7,58 \\
\hline$\eta_{\mathrm{EHK}} / \%$ & 79,53 & 62,84 & 94,31 & 81,30 & 82,44 & 96,37 \\
\hline
\end{tabular}

${ }^{\mathrm{c}}$ Celluclast 1.5L $+\beta$-glukozidaza, predhidroliza $48 \mathrm{~h}$ / Celluclast $1.5 \mathrm{~L}+\beta$-glucosidase, prehydrolysis for $48 \mathrm{~h}$; ${ }^{\mathrm{d}}$ Celluclast $1.5 \mathrm{~L}+$ Viscozyme $\mathrm{L}$, predhidroliza $48 \mathrm{~h} /$ Celluclast $1.5 \mathrm{~L}+$ Viscozyme $\mathrm{L}$, prehydrolysis for $48 \mathrm{~h}$; ${ }^{\mathrm{e}}$ Celluclast $1.5 \mathrm{~L}+$ $\beta$-glukozidaza, predhidroliza $96 \mathrm{~h} /$ Celluclast $1.5 \mathrm{~L}+\beta$-glucosidase, prehydrolysis for $96 \mathrm{~h}$; ${ }^{\mathrm{f}}$ Celluclast $1.5 \mathrm{~L}+$ Viscozyme $\mathrm{L}$, predhidroliza $96 \mathrm{~h} /$ Celluclast $1.5 \mathrm{~L}+$ Viscozyme $\mathrm{L}$, prehydrolysis for $96 \mathrm{~h}$; ${ }^{\mathrm{g}}$ Celluclast $1.5 \mathrm{~L}+\beta$-glukozidaza, predhidroliza $144 \mathrm{~h} /$ Celluclast $1.5 \mathrm{~L}+\beta$-glucosidase, prehydrolysis for $144 \mathrm{~h}$; ${ }^{\mathrm{h}}$ Celluclast $1.5 \mathrm{~L}+$ Viscozyme $\mathrm{L}$, predhidroliza $144 \mathrm{~h}$ / Celluclast $1.5 \mathrm{~L}+$ Viscozyme L, prehydrolysis for $144 \mathrm{~h}$; 

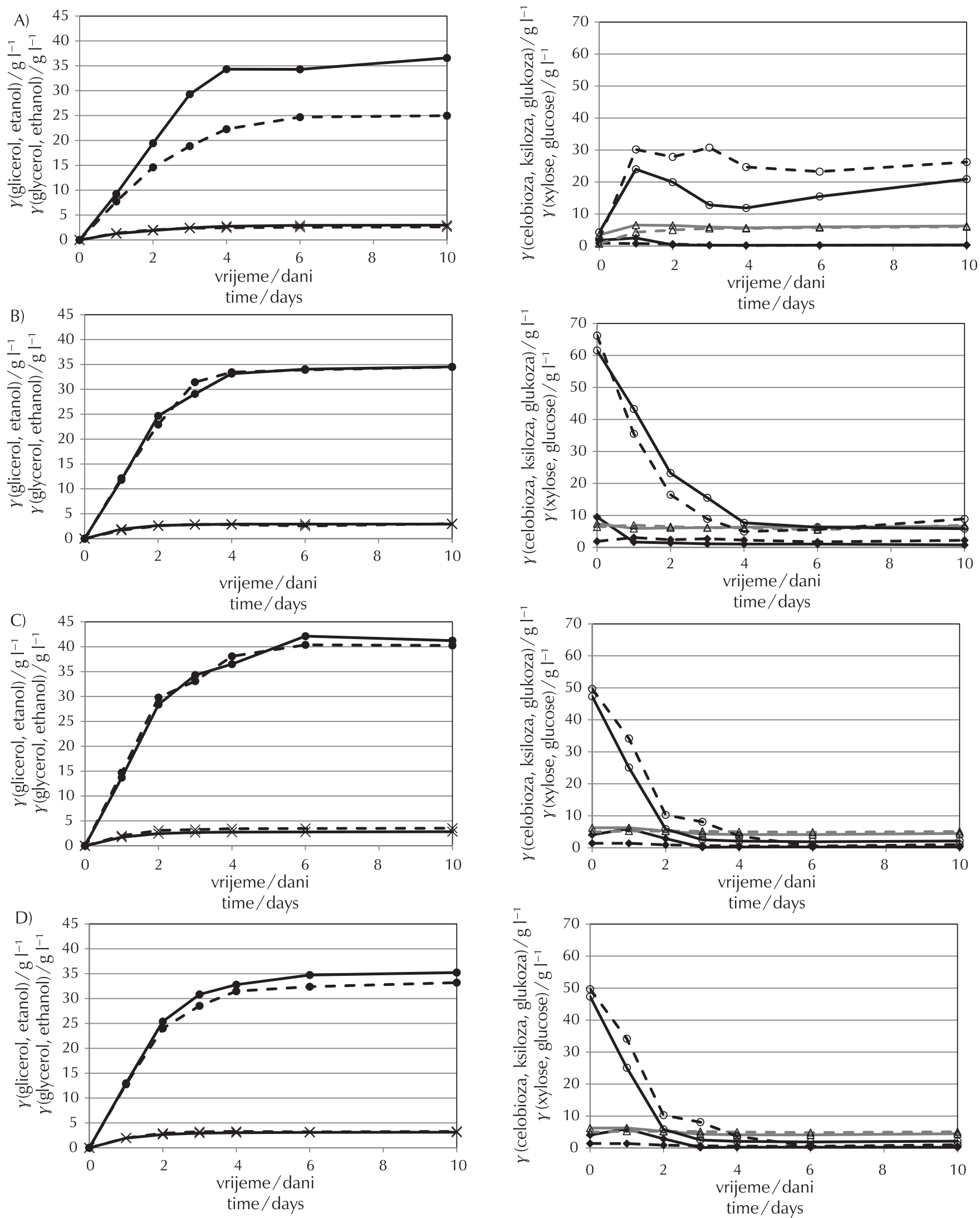

Slika 2 - Učinak enzimske predhidrolize na profile koncentracija glukoze $(\mathrm{o})$, celobioze $(\bullet)$, ksiloze $(\Delta)$, glicerola $(\times)$ i etanola $(\bullet)$ tijekom fermentacije hidrolizata predobrađenog kukuruznog oklaska uz primjenu enzimske smjese Celluclast $1.5 \mathrm{~L}+\beta$-glukozidazu (isprekidana crta) i Celluclast 1.5L + Viscozyme L (puna crta). Trajanje predhidrolize: 0 h (2A), 48 h (2B), 96 h (2C), te $144 \mathrm{~h}(2 \mathrm{D})$.

Fig. 2 - Effect of enzymatic prehydrolysis on profiles of glucose (o), cellobiose $(\bullet)$, xylose $(\Delta)$, glycerol $(x)$ and ethanol $(\bullet)$ during fermentation of corn cob hydrolysate using enzymatic mixtures Celluclast $1.5 \mathrm{~L}+\beta$-glucosidase (dashed line) and Celluclast 1.5L + Viscozyme L (solid line). Prehydrolysis time: $0 \mathrm{~h}(2 \mathrm{~A}), 48 \mathrm{~h}(2 \mathrm{~B}), 96 \mathrm{~h}(2 \mathrm{C})$ and $144 \mathrm{~h}(2 \mathrm{D})$. 
Tablica 3 - Pokazatelji učinkovitosti procesa proizvodnje bioetanola iz kukuruznog oklaska

Table 3 - Process efficiency parameters for production of bioethanol from corn cobs

\begin{tabular}{|c|c|c|c|c|c|c|c|c|}
\hline $\begin{array}{l}\text { Enzimski preparat/ } \\
\text { Enzyme preparation }\end{array}$ & A_ $\beta^{a}$ & A_Vb & B_ $\beta^{c}$ & B_V $V^{d}$ & $C \_\beta^{e}$ & $C_{-} V^{f}$ & D_ $\beta^{g}$ & D_ $V^{h}$ \\
\hline $\begin{array}{l}\text { predhidroliza/ } \\
\text { prehydrolysis / h }\end{array}$ & 0 & 0 & 48 & 48 & 96 & 96 & 144 & 144 \\
\hline$Y_{\mathrm{P} / \mathrm{S}} / \mathrm{gg}^{-1}$ glukana & 0,28 & 0,41 & 0,47 & 0,46 & 0,39 & 0,39 & 0,38 & 0,40 \\
\hline $\begin{array}{c}Y_{\mathrm{P} / \mathrm{NKO}} \\
/ \mathrm{gg}^{-1} \mathrm{DW} \_\mathrm{NKO}\end{array}$ & 0,08 & 0,12 & 0,14 & 0,14 & 0,12 & 0,12 & 0,11 & 0,12 \\
\hline$\eta / \%$ & 49,83 & 73,00 & 82,29 & 80,34 & 68,83 & 68,89 & 66,24 & 70,31 \\
\hline$\eta_{\mathrm{T}} / \%$ & 38,24 & 56,02 & 63,15 & 61,65 & 52,82 & 52,87 & 50,83 & 53,95 \\
\hline $\operatorname{Pr}^{\mathrm{i}} / \mathrm{gdm}^{-3} \mathrm{~h}^{-1}$ & 0,23 & 0,36 & 0,38 & 0,40 & 0,35 & 0,35 & 0,33 & 0,34 \\
\hline$P r_{\mathrm{T}}^{\mathrm{i}} / \mathrm{gdm}^{-3} \mathrm{~h}^{-1}$ & 0,23 & 0,36 & 0,25 & 0,26 & 0,17 & 0,18 & 0,14 & 0,15 \\
\hline
\end{tabular}

${ }^{a}$ Celluclast 1.5L $+\beta$-glukozidaza, bez predhidrolize / Celluclast $1.5 \mathrm{~L}+\beta$-glucosidase, no prehydrolysis step; ${ }^{\text {b } C e l l u c l a s t ~} 1.5 \mathrm{~L}+$ Viscozyme $\mathrm{L}$, bez predhidrolize / Celluclast $1.5 \mathrm{~L}+$ Viscozyme $\mathrm{L}$, no prehydrolysis step; ${ }^{\circ}$ Celluclast $1.5 \mathrm{~L}+\beta$-glukozidaza, predhidroliza $48 \mathrm{~h} /$ Celluclast 1.5L $+\beta$-glucosidase, prehydrolysis for $48 \mathrm{~h}$; ${ }^{d}$ Celluclast $1.5 \mathrm{~L}+$ Viscozyme L, predhidroliza $48 \mathrm{~h} /$ Celluclast $1.5 \mathrm{~L}+$ Viscozyme L, prehydrolysis for $48 \mathrm{~h}$; ${ }^{\mathrm{e}}$ Celluclast $1.5 \mathrm{~L}+\beta$-glukozidaza, predhidroliza $96 \mathrm{~h} /$ Celluclast $1.5 \mathrm{~L}+\beta$-glucosidase, prehydrolysis for $96 \mathrm{~h}$; ${ }^{\mathrm{f} C e}$ lluclast $1.5 \mathrm{~L}+$ Viscozyme $\mathrm{L}$, predhidroliza $96 \mathrm{~h} /$ Celluclast $1.5 \mathrm{~L}+$ Viscozyme $\mathrm{L}$, prehydrolysis for $96 \mathrm{~h} ;{ }^{\mathrm{g}}$ Celluclast $1.5 \mathrm{~L}+$

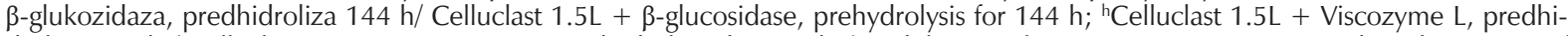
droliza $144 \mathrm{~h}$ / Celluclast 1.5L + Viscozyme L, prehydrolysis for $144 \mathrm{~h}$; iproduktivnost bioprocesa izračunata je 4. dana fermentacije/ bioprocess productivity calculated on $4^{\text {th }}$ day of fermentation

i C_V (četiri dana predhidrolize; slika 2C), te D_ $\beta$ i D_V (šest dana predhidrolize; slika 2D) kod kojih je početna koncentracija monosaharida bila nešto veća. Smanjenje brzine sinteze etanola najvjerojatnije je posljedica povećanog osmotskog tlaka u podlogama koji negativno utječe na vijabilnost, brzinu rasta te fermentacijska svojstva kvasca. ${ }^{38}$

Znatno manje brzine sinteze etanola uočene su u podlogama u kojima nije provedena predhidroliza (A_ $\beta$ i A_V; slika 2A). Brzina sinteze etanola u fermentaciji A_ $\beta$ iznosila je $0,28 \mathrm{~g} \mathrm{dm}^{-3} \mathrm{~h}^{-1}$, dok je u fermentaciji A $\vee$ bila znatno veća i iznosila je $0,41 \mathrm{~g} \mathrm{dm}^{-3} \mathrm{~h}^{-1}$ (tablica 3 ). N̄a samom početku uzgoja miješanje u tim podlogama bilo je otežano zbog povećane gustoće podloge. Celuloza u predobrađenoj sirovini veže vodu iz podloge, što ima posljedicu znatnog smanjenja količine slobodne vode. Količina vezane vode u celulozi ovisi o veličini pora, a ne stupnju polimerizacije vlakana i kristaličnosti celuloze. Smanjenjem sadržaja slobodne vode mijenjaju se reološka svojstva podloge što utječe na sile smicanja tijekom miješanja podloge. ${ }^{39}$ Voda je supstrat u enzimskoj reakciji hidrolize celuloze i nužna je za aktivnost enzima. Također je važna za vitalnost i fiziološku aktivnost stanica kvasaca, ali i za prijenos mase u podlozi (enzim, supstrat, te međuproizvodi i proizvodi staničnog metabolizma i enzimske reakcije). Učinkovitost enzimske hidrolize smanjuje se s povećanjem masenog udjela suhe tvari u podlozi iznad $10 \%$. Povećanjem masenog udjela supstrata u podlozi se povećava i prinos proizvoda, te se smanjuju troškovi izdvajanja proizvoda, kapitalni troškovi i troškovi proizvodnje. ${ }^{40,41} \mathrm{U}$ prvim satima uzgoja u podlozi bez provedene predhidrolize (smjese $\mathrm{A} \beta \mathrm{i} A \mathrm{~V}$ ) rast kvasca i sinteza etanola najvjerojatnije je bila ograničena dostupnošću limitirajućeg supstrata tj. glukoze. Nakon prvog dana fermentacije vizualnim promatranjem zamijećeno je smanjenje viskoznosti podloge i to samo u području oko mješača, dok je u vanjskom dijelu prema stijenki tikvice formiran nepomičan sloj sirovine. Drugog dana uzgoja čitav volumen podloge bio je homogen uz značajnije smanjenje viskoznosti. Naime, hidrolizom celuloze povećala se količina slobodne vode u podlozi. Opaženo smanjenje viskoznosti bilo je izraženije u podlozi $\mathrm{A} \vee \mathrm{u}$ odnosu na podlogu $A$, što se može pripisati različitoj supstratnoj specifičnosti upotrijebljenih enzimskih preparata, ali i većoj aktivnosti enzima izoliranih A. niger (Viscozyme L) što doprinosi bržoj hidrolizi sirovine. Iz navedenih razloga koncentracija etanola $\mathrm{u}$ fermentacijama $\mathrm{A} \vee \mathrm{V}$ i A $\beta$ bila je nešto niža $u$ odnosu na ostale fermentacije $s$ predhidrolizom. Također je koncentracija preostalog supstrata u tim uvjetima bila nešto veća. Koncentracija ksiloze se tijekom uzgoja nije znatnije mijenjala, jer kvasac $S$. cerevisiae ne koristi ksilozu kao izvor ugljika za rast. Na početku fermentacije u podlogama s dodanom $\beta$-glukozidazom (fermentacija $B \_\beta, C \_\beta$ i D $\beta$ ) koncentracija celobioze bila je znatno niža nego u podlogama uz dodatak Viscozyme $L$ (fermentacija B_V, C_V i D_V). Tijekom uzgoja, djelovanjem $\beta$-glukozidaze koncentracija celobioze postupno se smanjivala. Najveći prinos etanola od 0,47 i 0,46 $\mathrm{gg}^{-1}$ glukana postignut je u fermentacijama $B \_\beta$ i B $\vee V$ uz najkraće trajanje predhidrolize (tablica 3). Prinos bioetanola izračunat na izvornu sirovinu (neobrađeni kukuruzni oklasak) uključuje gubitke sirovine tijekom procesa predobrade, a iznosio je $0,14 \mathrm{gg}^{-1}$. Najveća produktivnost procesa proizvodnje etanola $(P r)$ postignuta je također u fermentacijama B_ $\beta$ i B _ V i iznosila je 0,38 i $0,40 \mathrm{~g} \mathrm{dm}^{-3} \mathrm{~h}^{-1}$. Uzimajući u obzir trajanje predhidrolize, najveća ukupna produktivnost procesa $\left(\operatorname{Pr}_{\mathrm{T}}\right)$ od $0,36 \mathrm{~g} \mathrm{dm}^{-3} \mathrm{~h}^{-1}$ postignuta je $\mathrm{u}$ fermentaciji bez predhidrolize uz dodatak enzimskog preparata Viscozyme L (A_V). Suprotno očekivanjima predhidroliza sirovine nije 
povećala ukupnu produktivnost procesa proizvodnje etanola. Manja produktivnost procesa SSF uz predhidrolizu sirovine u odnosu na konvencionalan proces SSF vjerojatno je posljedica djelovanja okolišnih uvjeta na celulolitičke enzime, ali i na radni mikroorganizam. Povišena temperatura kojoj je enzim izložen tijekom predhidrolize smanjuje celulolitičku aktivnost enzima, a time i dostupnost izvora ugljika. ${ }^{15}$ Osim toga, radni mikroorganizam u podlozi izložen je povećanom osmotskom tlaku zbog visoke koncentracije šećera i mineralnih soli iz predobrađene lignocelulozne sirovine. Kao odgovor na osmotski stres stanica kvasca sintetizira glicerol kako bi kompenzirala porast tlaka u okolini stanice. Glicerol također ima važnu ulogu u preživljavanju stanica u uvjetima niže vodene aktivnosti. ${ }^{42}$

Provođenjem stupnja predhidrolize povećao se koeficijent konverzije procesa SSF. Najkraće trajanje predhidrolize od dva dana pokazalo se najpogodnijim za ostvarivanje najvećeg iskorištenja bioprocesa. Vrijednost koeficijenta konverzije supstrata u etanol iznosila je $0,47 \mathrm{gg}^{-1}$ glukana, što odgovara iskorištenju od čak $82,3 \%$. Vrijednosti pokazatelja uspješnosti u ovom radu nešto su veće od vrijednosti dobivenih u procesu SSF proizvodnje bioetanola iz kukuruzne stabljike predobrađene $\mathrm{s}$ natrijevom lužinom uz 16 sati predhidrolize $\left(\operatorname{Pr}_{\mathrm{T}}=0,33 \mathrm{~g} \mathrm{dm}^{-3} \mathrm{~h}^{-1} \mathrm{i} Y_{\mathrm{S} / \mathrm{P}}=0,321 \mathrm{gg}^{-1}\right) .^{43}$ Predhidroliza sirovine nije povećala ukupnu produktivnost procesa proizvodnje bioetanola, što je najvjerojatnije posljedica predugog trajanja predhidrolize. Zbog toga bi u nastavku istraživanja bilo potrebno istražiti učinak kraćeg vremena predhidrolize $(<48$ h) na učinkovitost procesa proizvodnje bioetanola postupkom SSF.

\section{Zaključci}

U ovom radu istražen je učinak predhidrolize na učinkovitost procesa proizvodnje bioetanola postupkom SSF iz predobrađenog kukuruznog oklaska s kvascem $S$. cerevisiae uz dodatak $\beta$-glukozidaze i enzimskog preparata Viscozyme L. Da bi se poboljšala učinkovitost enzimske hidrolize, lignocelulozna sirovina je predobrađena s natrijevom lužinom, čime je smanjen udjel lignina i ksilana, dok se udjel glukana povećao. Predhidrolizom sirovine smanjena je ukupna produktivnost procesa proizvodnje bioetanola, dok su stupanj konverzije supstrata u bioetanol i iskorištenje procesa povećani. U procesu SSF uz predhidrolizu sirovine u trajanju od $48 \mathrm{~h}$ postignut je najveći prinos etanola od 0,47 $\mathrm{g} \mathrm{g}^{-1}$. Maksimalna ukupna produktivnost procesa od $0,36 \mathrm{~g} \mathrm{dm}^{-3} \mathrm{~h}^{-1}$ postignuta je u procesu SSF bez predhidrolize sirovine. Uvođenjem predhidrolize lignocelulozne sirovine znatno je smanjenja viskoznost podloge što bi moglo smanjiti utrošak energije za miješanje podloge uz pomoć pumpe ili miješala neposredno prije SSF-a. Dodatkom Viscozyme $L$ viskoznost podloge brže se smanjila nego uz dodatak $\beta$-glikozidaze. Upotrebom Viscozyme L i $\beta$-glukozidaze postignute su slične vrijednosti pokazatelja učinkovitosti procesa SSF uz predhidrolizu sirovine.

\section{ZAHVALA}

Ovaj rad financirala je Hrvatska zaklada za znanost projektom 9158 Sustainable production of bioethanol and biochemicals from agricultural waste lignocellulosic raw materials (SPECH-LRM).

\section{Popis kratica i simbola List of abbreviations and symbols}

\begin{tabular}{|c|c|}
\hline$A_{205}$ & $\begin{array}{l}\text { - apsorbancija uzorka pri } 205 \mathrm{~nm} \\
\text { - sample absorbance at } 205 \mathrm{~nm}\end{array}$ \\
\hline$b$ & $\begin{array}{l}\text { - širina kivete, } 1 \mathrm{~cm} \\
\text { - cuvette width, } 1 \mathrm{~cm}\end{array}$ \\
\hline$D$ & $\begin{array}{l}\text { - faktor razrjeđenja uzorka } \\
\text { - sample dilution factor }\end{array}$ \\
\hline$K_{\mathrm{f}}$ & $\begin{array}{l}\text { - korektivni faktor (za pentoze } 0,88 \text { i heksoze } 0,9 \text { ) } \\
\text { - correction factor (for pentoses } 0.88 \text { and hexoses } 0.9 \text { ) }\end{array}$ \\
\hline$m$ & $\begin{array}{l}\text { - masa uzorka, g } \\
\text { - sample weight, g }\end{array}$ \\
\hline$m_{\mathrm{CHO}}$ & $\begin{array}{l}\text { - masa strukturnog ugljikohidrata u predobrađenom } \\
\text { kukuruznom oklasku, g } \\
\text { - weight of structural carbohydrate in pretreated corn } \\
\text { cobs, g }\end{array}$ \\
\hline$m_{\text {glukan }}$ & $\begin{array}{l}\text { - masa glukana u predobrađenom kukuruznom } \\
\text { oklasku, g } \\
\text { - weight of glucan in pretreated corn cobs, g }\end{array}$ \\
\hline$m_{\text {glukan,ОКО }}$ & $\begin{array}{l}\text { - masa glukana u predobrađenom kukuruznom } \\
\text { oklasku, g } \\
\text { - weight of glucan in pretreated corn cobs, g }\end{array}$ \\
\hline$m_{\text {msah }}$ & $\begin{array}{l}\text { - masa monosaharida (glukoza, ksiloza) u enzimskom } \\
\text { hidrolizatu, g } \\
\text { - weight of monosaccharide (glucan, xylan) in } \\
\text { enzymatic hydrolysate, g }\end{array}$ \\
\hline$m_{\mathrm{NKO}}$ & $\begin{array}{l}\text { - masa neobrađenog kukuruznog oklaska, g } \\
\text { - weight of untreated corn cobs, g }\end{array}$ \\
\hline$m_{\mathrm{P}}$ & $\begin{array}{l}\text { - masa dobivenog etanola, } g \\
\text { - weight of produced ethanol, g }\end{array}$ \\
\hline $\operatorname{Pr}$ & $\begin{array}{l}\text { - produktivnost bioprocesa, } \mathrm{gdm}^{-3} \mathrm{~h}^{-1} \\
\text { - bioprocess productivity, } \mathrm{g} \mathrm{dm}^{-3} \mathrm{~h}^{-1}\end{array}$ \\
\hline$P r_{\mathrm{T}}$ & $\begin{array}{l}\text { - ukupna produktivnost bioprocesa, } \mathrm{g} \mathrm{dm}^{-3} \mathrm{~h}^{-1} \\
\text { - total bioprocess productivity, } \mathrm{g} \mathrm{dm}^{-3} \mathrm{~h}^{-1}\end{array}$ \\
\hline$t$ & $\begin{array}{l}\text { - trajanje fermentacije, } \mathrm{h} \\
\text { - fermentation time, } \mathrm{h}\end{array}$ \\
\hline V & $\begin{array}{l}\text { - volumen, I } \\
\text { - volume, I }\end{array}$ \\
\hline$w(\mathrm{ASL})$ & $\begin{array}{l}\text { - udjel lignina topljivog u kiselini, \% } \\
\text { - content of acid soluble lignin, \% }\end{array}$ \\
\hline$w_{\mathrm{CHO}}$ & $\begin{array}{l}\text { - udjel ugljikohidrata, } \% \\
\text { - carbohydrate content, } \%\end{array}$ \\
\hline$Y_{\mathrm{P} / \mathrm{NKO}}$ & $\begin{array}{l}\text { - ukupni stupanj konverzije neobrađenog kukuruznog } \\
\text { oklaska u etanol, g g } \\
\text { - total conversion rate of ethanol based on untreated } \\
\text { corn cobs, } \mathrm{gg}^{-1}\end{array}$ \\
\hline
\end{tabular}




\begin{tabular}{|c|c|}
\hline$Y_{\mathrm{P} / \mathrm{S}}$ & $\begin{array}{l}\text { - stupanj konverzije susptrata u proizvod izračunat } \\
\text { na količinu glukana u predobrađenom kukuruznom } \\
\text { oklasku, g g } \\
\text { - ethanol conversion rate calculated based on glucan } \\
\text { in pretreated corn cobs, } \mathrm{gg}^{-1}\end{array}$ \\
\hline$Y_{\mathrm{P} / \text { theoret }}$ & $\begin{array}{l}\text { - teoretski stupanj konverzije glukana u etanol, } \\
\text { 0,567 } \mathrm{g} \mathrm{g}^{-1} \\
\text { - theoretical conversion rate of ethanol from glucan, } \\
0,567 \mathrm{~g} \mathrm{~g}^{-1}\end{array}$ \\
\hline$\alpha$ & $\begin{array}{l}\text { - apsorpcijski koeficijent, } 110 \mathrm{dm}^{3} \mathrm{~g}^{-1} \mathrm{~cm}^{-1} \\
\text { - absorption coefficient, } 110 \mathrm{dm}^{3} \mathrm{~g}^{-1} \mathrm{~cm}^{-1}\end{array}$ \\
\hline$\gamma_{\text {msah }}$ & $\begin{array}{l}\text { - koncentracija monosaharida, } \mathrm{g} \mathrm{dm}^{-3} \\
\text { - concentration of monosaccharide, } \mathrm{g} \mathrm{dm}^{-3}\end{array}$ \\
\hline$\eta$ & $\begin{array}{l}\text { - iskorištenje bioprocesa, \% } \\
\text { - bioprocess recovery, \% }\end{array}$ \\
\hline$\eta_{\mathrm{PB}}$ & $\begin{array}{l}\text { - iskorištenje glukana procesu predobrade, } \%, \\
\text { - recovery of glucan in pretreatment process, \% }\end{array}$ \\
\hline$\eta_{\mathrm{EHG}}$ & $\begin{array}{l}\text { - iskorištenje enzimske hidrolize glukana, \% } \\
\text { - efficiency of enzymatic hydrolysis of glucan, \% }\end{array}$ \\
\hline$\eta_{\mathrm{EHK}}$ & $\begin{array}{l}\text { - iskorištenje enzimske hidrolize ksilana, \% } \\
\text { - efficiency of enzymatic hydrolysis of xylan, \% }\end{array}$ \\
\hline$\eta_{\mathrm{T}}$ & $\begin{array}{l}\text { - ukupno iskorištenje bioprocesa, \% } \\
\text { - total bioprocess recovery, \% }\end{array}$ \\
\hline
\end{tabular}

\section{Literatura \\ References}

1. F. H. Isikgor, C. R. Becer, Lignocellulosic biomass: a sustainable platform for the production of bio-based chemicals and polymers, Polym. Chem. 6 (25) (2015) 4497-4559, doi: https://doi.org/10.1039/C5PY00263J.

2. M. Ivančić Šantek, E. Miškulin, S. Beluhan, B. Šantek, Novi trendovi u proizvodnji etanola kao biogoriva, Kem. Ind. 65 (2016) 25-38, doi: https://doi.org/10.15255/KUI.2014.032.

3. URL: http://www.biobasedpress.eu/2016/02/cellulosic-ethanol-feedstock-costs-predominant-sugar-cane-cheapest/ (21. 10. 2016.).

4. B. Volynets, Y. Dahman, Assessment of pretreatments and enzymatic hydrolysis of wheat straw as a sugar source for bioprocess industry, Int. J. Eng. Environ. 2 (2011) 427-446.

5. A. Demirbas, Potential applications of renewable energy sources, biomass combustion problems in boiler power systems and combustion related environmental issues, Prog. Energy Combus. Sci. 31 (2005) 171-192, doi: https://doi. org/10.1016/j.pecs.2005.02.002.

6. R. L. Howard, E. Abotsi, E. J, Van Rensburg, S. Howard, Lignocellulose biotechnology: issues of bioconversion and enzyme production, Afr. J. Biotechnol. 2(12) (2003) 602-619, doi: https://doi.org/10.5897/AJB2003.000-1115.

7. J. Pérez, J. Munoz-Dorado, T. D. L. R. de la Rubia, J. Martinez, Biodegradation and biological treatments of cellulose, hemicellulose and lignin: an overview, Int. Microbiol. 5 (2) (2002) 53-63, doi: https://doi.org/10.4172/2155-6199.1000e172.

8. R. H. Bischof, J. Ramoni, B. Seiboth, Cellulases and beyond: the first 70 years of the enzyme producer Trichoderma reesei, Microb. Cell Fact. 15 (1) (2016) 1, doi: https://doi. org/10.1186/s12934-016-0507-6.

9. Y. H. P. Zhang, S. Y. Ding, J. R. Mielenz, J. B. Cui, R. T. Elander, M. Laser, L. R. Lynd, Fractionating recalcitrant lignocellulose at modest reaction conditions, Biotechnol. Bioeng. 97 (2) (2007) 214-223, doi: https://doi.org/10.1002/bit.21386.

10. P. Kumar, D. M. Barrett, M. J. Delwiche, P. Stroeve, Methods for pretreatment of lignocellulosic biomass for efficient hy- drolysis and biofuel production, Ind. Eng. Chem. Res. 48 (8) (2009) 3713-3729, doi: https://doi.org/10.1021/ie801542g.

11. R. A. Silverstein, Y. Chen, R. R. Sharma-Shivappa, M. D. Boyette, J. Osborne, A comparison of chemical pretreatment methods for improving saccharification of cotton stalks, Biores. Technol. 98 (2007) 3000-3011, doi: https://doi. org/10.1016/j.biortech.2006.10.022.

12. W. E. Kaar, M. T. Holtzapple, Using lime pretreatment to facilitate the enzymatic hydrolysis of corn stover, Biomass Bioenerg. 18 (2000) 189-99, doi: https://doi.org/10.1016/ S0961-9534(99)00091-4.

13. V. S. Chang, M. T. Holtzapple, Fundamental factors affecting biomass enzymatic reactivity, Appl. Biochem. Biotech. 84-86 (2000) 5-37, doi: https://doi.org/10.1385/ABAB:8486:1-9:5.

14. Y. Chen, M. A. Stevens, Y. Zhu, J. Holmes, H. Xu, Understanding of alkaline pretreatment parameters for corn stover enzymatic saccharification, Biotechnol. Biofuels 6 (1) (2013) 1, doi: https://doi.org/10.1186/1754-6834-6-8.

15. K. Öhgren, J. Vehmaanperä, M. Siika-aho, M. Galbe, L, Viikari, G Zacchi, High temperature enzymatic prehydrolysis prior to simultaneous saccharification and fermentation of steam pretreated corn stover for ethanol production, Enzyme Microb. Technol. 40 (2007) 607-613, doi: https://doi. org/10.1016/j.enzmictec.2006.05.014.

16. K. Öhgren, R. Bura, G. Lesnicki, J. Saddler, G. Zacchi, A comparison between simultaneous saccharification and fermentation and separate hydrolysis and fermentation using steam-pretreated corn stover, Process Biochem. 42 (5) (2007) 834-839, doi: https://doi.org/10.1016/j. procbio.2007.02.003.

17. T. K. Ghose, Measurement of cellulase activities, Pure Appl. Chem. 59(2) (1987) 257-268, doi: https://doi.org/10.1351/ pac198759020257.

18. Y. P. Zhang, J. Hong, X. Ye, Cellulase assays. Biofuels: methods and protocols (2009) 213-231. doi: https://doi. org/10.1007/978-1-60761-214-8_14.

19. A. Sluiter, B. Hames, R. Ruiz, C. Scarlata, J. Sluiter, D. Templeton, D. Crocke (2008). Laboratory analytical procedure (LAP): Determination of structural carbohydrates and lignin in biomass. Technical report: NREL/TP-510-42618. Golden, Colorado, USA National Renewable Energy Laboratory.

20. K. Gao, L. Rehmann, ABE fermentation from enzymatic hydrolysate of $\mathrm{NaOH}$-pretreated corncobs, Biomass Bioenerg. 66 (2014) 110-115, doi: https://doi.org/10.1016/j.biombioe.2014.03.002.

21. Y. Chen, M. A.Stevens, Y. Zhu, J. Holmes, H Xu, Understanding of alkaline pretreatment parameters for corn stover enzymatic saccharification, Biotechnol. biofuels 6(1) (2013) 1, doi: https://doi.org/10.1186/1754-6834-6-8.

22. K. Gao, S. Boiano, A. Marzocchella, L. Rehmann, Cellulosic butanol production from alkali-pretreated switchgrass (Panicum virgatum) and phragmites (Phragmites australis), Bioresour. Technol. 174 (2014) 176-181, doi: https://doi. org/10.1016/j.biombioe.2015.03.016.

23. T. De Vrije, R. R., Bakker, M. A. Budde, M. H Lai, A. E. Mars, P. A. Claassen, Efficient hydrogen production from the lignocellulosic energy crop Miscanthus by the extreme thermophilic bacteria Caldicellulosiruptor saccharolyticus and Thermotoga neapolitana, Biotechnol. Biofuel. 2 (1) (2009) 12, doi: https://doi.org/10.1186/1754-6834-2-12.

24. P. Ghosh, N. B. Pamment, W. R. B. Martin, Simultaneous saccharification and fermentation of cellulose: Effect of $\beta$-glucosidase activity and ethanol inhibition of cellulases, Enzyme Microb. Technol. 4 (6) (1982) 425-430, doi: https://doi. org/10.1002/bit.260270402. 
25. O. Faix, Classification of lignins from different botanical origins by FT-IR spectroscopy, Holzforschung, 45 (s1) (1991) 21-28, doi: https://doi.org/10.1063/1674-0068/28/ cjcp1502014.

26. S. P. Chundawat, B. Venkatesh, B. E. Dale, Effect of particle size based separation of milled corn stover on AFEX pretreatment and enzymatic digestibility, Biotechnol. bioeng. 96(2) (2007) 219-231, doi: https://doi.org/10.1002/bit.21132.

27. E. R. Hage, N. Brosse, L. Chrusciel, C. Sanchez, P. Sannigrahi, A. Ragauskas, Characterization of milled wood lignin and ethanol organosolv lignin from miscanthus, Polym. Degrad. Stab. 94 (10) (2009) 1632-1638, doi: https://doi. org/10.1016/j.polymdegradstab.2009.07.007.

28. F. E. M, Van Dongen, D. Van Eylen, M. A. Kabel, Characterization of substituents in xylans from corn cobs and stover, Carbohydr. Polym. 86 (2) (2011) 722-731, doi: https://doi. org/10.1016/j.carbpol.2011.05.007.

29. X. Colom, F. Carrillo, Crystallinity changes in lyocell and viscose-type fibres by caustic treatment, Eur. Polym. J. 38 (11) (2002) 2225-2230, https://doi.org/10.1016/S00143057(02)00132-5.

30. W. X., Peng, L. S. Wang, O. Makoto, M. L. Zhang, Separation of hemicelluloses from Eucalyptus species: investigating the residue after alkaline treatment, Cellul. Chem. Technol. 49 (2015) 756-764, doi: http://doi.org/10.1016/j. jsps.2016.04.005.

31. S. Y. Oh, D. I. Yoo, Y, Shin, H. C. Kim, H. Y. Kim, Y. S, Chung, J. H. Youk, Crystalline structure analysis of cellulose treated with sodium hydroxide and carbon dioxide by means of X-ray diffraction and FTIR spectroscopy, Carbohydr. Res. 340 (15) (2005) 2376-2391, doi: https://doi.org/10.1016/j. carres.2005.08.007.

32. M. Kacurakova, P. Capek, V. Sasinkova, N. Wellner, A. Ebringerova, FT-IR study of plant cell wall model compounds: pectic polysaccharides and hemicelluloses, Carbohydr. polym. 43 (2) (2000) 195-203, doi: https://doi.org/10.1016/S01448617(00)00151-X.

33. R. Zuluaga, J. L. Putaux, J. Cruz, J. Vélez, I. Mondragon, P. Gañán, Cellulose microfibrils from banana rachis: Effect of alkaline treatments on structural and morphological features, Carbohydr. Polym. 76 (1) (2009) 51-59, doi: https://doi. org/10.1016/j.carbpol.2008.09.024.
34. K. K. Oh, S. W. Kim, Y. S. Jeong, S. I. Hong, Bioconversion of cellulose into ethanol by nonisothermal simultaneous saccharification and fermentation, Appl. Biochem. Biotechnol. 89 (1) (2000) 15-30, doi: https://doi.org/10.1385/ ABAB:89:1:15.

35. R. Kumar, C. E. Wyman, Effect of enzyme supplementation at moderate cellulase loadings on initial glucose and xylose release from corn stover solids pretreated by leading technologies, Biotechnol. Bioeng. 102 (2) (2009) 457-467, doi: https://doi.org/10.1002/bit.22068.

36. https://www.novozymes.com/en/-/media/Novozymes/ en/solutions/bioenergy/starch-based-ethanol/viscosity-reduction/Viscozyme/Documents/Viscozyme-Wheat-HT. pdf; http://www.sigmaaldrich.com/catalog/product/sigma/ v2010?lang (pristupljeno 11. 2. 2016.).

37. D. J. Ahn, S. K. Kim, H. S. Yun, Optimization of pretreatment and saccharification for the production of bioethanol from water hyacinth by Saccharomyces cerevisiae, Bioproc. Biosyst. Eng. 35 (1-2) (2012) 35-41, doi: https://doi. org/10.1007/s00449-011-0600-5.

38. P. L. Pratt, J. H. Bryce, G. G. Stewart, The effects of osmotic pressure and ethanol on yeast viability and morphology, J. Inst. Brew. 109 (2003) 218-228, doi: https://doi. org/10.1002/j.2050-0416.2003.tb00162.x.

39. H. Jørgensen, J. Vibe-Pedersen, J. Larsen, C. Felby, Liquefaction of lignocellulose at high solids concentrations, Biotechnol. Bioeng. 96 (2007) 862-870, doi: https://doi. org/10.1002/bit.21115.

40. J. B. Kristensen, C. Felby, H. Jorgensen, Yield-determining factors in high-solids enzymatic hydrolysis of lignocellulose, Biotechnol. Biofuels. 2 (2009) 11, doi: https://doi. org/10.1186/1754-6834-2-11.

41. P. Gervais, P. Molin, The role of water in solid-state fermentation, Bioche. Eng. J. 13 (2) (2003) 85-101, doi: https://doi. org/10.1007/BF00451620.

42. E. Nevoigt, Progress in Metabolic Engineering of Saccharomyces cerevisiae, Microbiol. Mol. Biol. Rev. 72 (3) (2008) 379-412, doi: https://doi.org/10.1128/MMBR.00025-07.

43. J. Zhao, L. Xia, Simultaneous saccharification and fermentation of alkaline-pretreated corn stover to ethanol using a recombinant yeast strain, Fuel Process. Technol. 90 (2009) 1193-1197, doi: https://doi.org/10.1016/j. fuproc.2009.05.018. 


\title{
SUMMARY
}

\section{Production of Bioethanol from Corn Cobs}

\author{
Mirela Ivančić Šantek, Ines Zvonar, Sunčica Beluhan, and Božidar Šantek
}

Bioethanol was produced from cellulase-hydrolysed pretreated corn cobs by simultaneous saccharification and fermentation (SSF) with yeast Saccharomyces cerevisiae. The effect of the duration of the corn cob prehydrolysis step on ethanol yield by SSF process was studied and compared to the conventional SSF process. Two mixtures of commercially available enzyme preparations were used for biomass hydrolysis; the first contained Celluclast 1.5L (Sigma) and ß-glucosidase (Carl Roth), and the second mixture contained Celluclast 1.5L (Sigma) and Viscozyme L (Sigma). Two days of prehydrolysis had a positive effect on ethanol yield, while the yield decreased with longer prehydrolysis. The highest ethanol concentration of $41.24 \mathrm{~g} \mathrm{dm}^{-3}$ was obtained by SSF process with two days of prehydrolysis, which corresponded to $63.15 \%$ of the theoretical yield based on untreated corn cobs. However, the highest total productivity of $0.36 \mathrm{~g} \mathrm{dm}^{-3} \mathrm{~h}^{-1}$ was observed in conventional SSF process using enzyme mixture containing Celluclast 1.5L (Sigma) and Viscozyme $\mathrm{L}$ (Sigma). Concentration of ethanol was $36.6 \mathrm{~g} \mathrm{dm}^{-3}$ which corresponded to $56.02 \%$ of the theoretical yield based on untreated corn cobs.

\section{Keywords}

Corn cobs, bioethanol, cellulases, simultaneous saccharification and fermentation, prehydrolysis

Faculty of Food Technology and Biotechnology

University of Zagreb

Pierottijeva 6

10000 Zagreb, Croatia
Original scientific paper Received November 22, 2017 Accepted February 11, 2018 